\title{
Trudności językowe i szkolne u 8-letniego chłopca z zaburzeniami przetwarzania stuchowego - studium przypadku
}

\section{Language and learning difficulties of an 8-year-old boy with auditory processing disorders - case study}

\author{
Karolina Samsonowicz, Anna Skoczylas, Małgorzata Fludra, Anna Geremek-Samsonowicz
}

Instytut Fizjologii i Patologii Słuchu, Światowe Centrum Słuchu, Klinika Rehabilitacji, Warszawa/Kajetany

Adres autora: Karolina Samsonowicz, Światowe Centrum Słuchu, Klinika Rehabilitacji, ul. Mokra 17, Kajetany, 05-830 Nadarzyn, e-mail: k.samsonowicz@ifps.org.pl

\section{Streszczenie}

Wprowadzenie: Prawidłowo funkcjonujący narząd słuchu umożliwia dostęp do języka mówionego i odgrywa ogromną rolę w rozwoju mowy i komunikacji. U wielu dzieci proces ten bywa zaburzony, a ich zdolność do skutecznego porozumiewania nie rozwija się w sposób harmonijny. W ostatnich latach obserwuje się duże zainteresowanie problemem zaburzeń przetwarzania słuchowego ze względu na możliwość istnienia związku z zaburzeniami językowymi oraz trudnościami w uczeniu się. Poznanie istoty tej relacji jest jednym z ważnych kierunków badań nad zaburzeniami słuchu i mowy u dzieci.

Cel: Celem pracy jest przedstawienie studium przypadku dziecka z deficytem językowym i trudnościami szkolnymi, u którego stwierdzono współistniejące zaburzenia przetwarzania słuchowego.

Materiał i metoda: Analiza dotyczy 8-letniego chłopca - ucznia II klasy szkoły podstawowej, objętego specjalistyczną opieką w Instytucie Fizjologii i Patologii Słuchu (IFPS) ze względu na utrzymujące się mimo prowadzonej terapii logopedycznej problemy językowe i artykulacyjne, narastające trudności szkolne oraz szereg problemów słuchowych. U dziecka wykonano podstawową diagnostykę audiologiczną (AT, AI, TEOAE), testy centralnych funkcji słuchowych (FPT, DPT, DDT), przeprowadzono ocenę psychologiczną (WISC-R, Skala Ryzyka Dysleksji) oraz logopedyczną (ocena mowy czynnej i biernej, artykulacji oraz słuchu fonemowego). Dodatkowo zastosowano wybrane testy uwagi z baterii Test of Attention Performance.

Wyniki i wnioski: Wyniki przeprowadzonej diagnostyki wskazały na współistnienie u chłopca deficytu językowego (hipoteza SLI), zaburzeń artykulacji, zaburzeń przetwarzania słuchowego oraz wysokiego ryzyka dysleksji. W testach psychologicznych stwierdzono statystycznie istotną różnicę pomiędzy wynikami w skali werbalnej i niewerbalnej. Wnioski z przeprowadzonych badań potwierdziły konieczność interdyscyplinarnego podejścia w postępowaniu diagnostycznym zaburzeń słuchu i mowy u dzieci, co umożliwia dobranie odpowiednich form terapii, sformułowanie zaleceń do stosowania w środowisku szkolnym oraz wskazówek służących do wypracowywania strategii radzenia sobie z deficytami.

Słowa kluczowe: zaburzenia przetwarzania słuchowego • SLI • dysleksja • diagnoza APD

Abstract

Introduction: The correct functioning of the auditory organ provides access to spoken language and plays an important role in the development of speech and communication. For many children this process can sometimes be disturbed and their abilities to communicate effectively do not develop in a harmonious way. In recent years there has been great interest in the problem of auditory processing disorders due to a potential link between APD, language disorders and learning difficulties. Determining the essence of this relationship is defined as one of the most important directions of research on speech and hearing disorders in children.

Aim: This work aims to present a case study of a child with language deficits and learning difficulties, who has been diagnosed with coexisting auditory processing disorders. 
Material and methods: The work is an analysis of the case of an 8 -year-old boy, a $2^{\text {nd }}$ grade student. The boy has been provided with specialist care at the IFPS due to persisting language and articulation problems (despite an ongoing speech therapy), increasing learning difficulties, and a number of auditory problems. Audiology diagnostics (PTA, tympanometry, TEOAE), tests of central auditory functions (FPT, DPT, DDT), psychological assessment (WISC - R, Risk of Dyslexia Scale) and speech and language assessment (production and perception of speech, articulation and phonemic hearing) have been provided. Selected tests from the Test of Attention Performance battery have been performed additionally.

Results and conclusions: The results of the diagnostics indicate the coexistence of language deficits (SLI hypothesis), articulation disorders, auditory processing disorders, and a high risk of dyslexia. The psychological tests showed statistically significant discrepancy between the results on a verbal and nonverbal scale. The findings confirm the need for a multidisciplinary approach in the diagnostics of speech and hearing disorders in children. It allows to selecting appropriate forms of therapy, making recommendations for school environment and provides guidelines in handling patient's disorders by developing compensatory strategies.

Key words: auditory processing disorders $\bullet$ SLI $\bullet$ dyslexia $\bullet$ APD diagnosis

\section{Wprowadzenie}

Istnieje grupa dzieci w wieku wczesnoszkolnym, u których pomimo prawidłowej czułości słuchu obserwuje się zachowania mogące wskazywać na niedosłuch. Dzieci takie mogą $\mathrm{m}$.in. nie radzić sobie $\mathrm{z}$ rozumieniem mowy na tle innych bodźców akustycznych, błędnie interpretować kierowane do nich pytania i w konsekwencji tworzyć nieadekwatne odpowiedzi, mieć trudności z rozumieniem dłuższych poleceń i zapamiętywaniem informacji podawanych drogą słuchową [1-4]. Takie objawy mogą sugerować występowanie zaburzeń przetwarzania słuchowego (ang. Auditory Processing Disorders, APD) ${ }^{1}$.

W ostatnich latach obserwuje się zarówno na świecie, jak i w Polsce wzmożone zainteresowanie zagadnieniem zaburzeń przetwarzania słuchowego. Skutkuje to nie tylko wzrostem świadomości dotyczącej istnienia tych zaburzeń w praktyce klinicznej, lecz także większymi wątpliwościami odnośnie diagnozy i metod terapii. W rezultacie termin „zaburzenia przetwarzania słuchowego" często nie jest używany precyzyjnie, a etykieta APD nadawana jest szerokiemu spektrum trudności [2]. Istnieje wiele definicji zaburzeń przetwarzania słuchowego, m.in. ze względu na brak konsensusu w kwestii określenia, czym jest samo zjawisko przetwarzania słuchowego [5]. Według ASHA (American Speech-Language-Hearing Association) procesy przetwarzania słuchowego odnoszą się do skutecznego i efektywnego wykorzystania informacji słuchowej przez OUN [6]. W definicji Katza, często przytaczanej w literaturze, centralne zaburzenia przetwarzania słuchowego opisywane są jako niemożność pełnego wykorzystywania sygnału akustycznego przy prawidłowym jego odbiorze w strukturach obwodowych [7]. Amerykańscy badacze Chermak i Musiek twierdzą, że ok. 2-3\% populacji pomimo prawidłowej czułości słuchu ma różnego rodzaju trudności słuchowe [8]. Eksperci ASHA w raporcie z 2005 roku [9] uznają, że można postawić rozpoznanie centralnych zaburzeń przetwarzania słuchowego, jeżeli co najmniej jedna z poniżej wymienionych wyższych funkcji słuchowych jest zaburzona:

- lokalizacja źródła dźwięku,

- różnicowanie dźwięków,

- rozpoznawanie wzorców dźwięków,
- analiza czasowych aspektów sygnału dźwiękowego,

- umiejętność rozumienia mowy zniekształconej,

- umiejętność rozumienia mowy w obecności sygnału zagłuszającego.

BSA (British Society of Audiology) podkreśla, że zaburzenia przetwarzania słuchowego wpływają na codzienne funkcjonowanie jednostki poprzez zredukowaną możliwość słuchania dźwięków, a więc i odpowiedzi na nie, przy czym termin „słuchanie” (ang. listening), który odnosi się do zwracania swojej uwagi na dźwięk, przeciwstawiony jest tu „słyszeniu” (ang. hearing), które jest procesem bardziej pasywnym [10]. Zaburzenia przetwarzania słuchowego charakteryzuje zubożona percepcja zarówno dźwięków niewerbalnych, jak i dźwięków mowy [10].

W piśmiennictwie podaje się także, że dzieci z APD mogą mieć problemy językowe, zaburzenia artykulacji oraz trudności szkolne obejmujące m.in. naukę czytania $[1,3,4,8,10,11]$. Prace badające rolę przetwarzania słuchowego w zaburzeniach komunikacji prowadzone są już od kilku dekad [12]. ASHA podając, że APD może prowadzić (ang. lead) lub być kojarzone (ang. be associated) $\mathrm{z}$ występowaniem trudności językowych i szkolnych, zwraca zarazem uwagę, że ich wzajemna zależność nie jest łatwa do określenia i niewskazane jest automatyczne łączenie tych deficytów [9]. Nie wszystkie dzieci z APD mają trudności językowe i szkolne, nie wszystkim zaburzeniom mowy i problemom w uczeniu się towarzyszy APD [1,9]. Nie osiągnięto konsensusu co do ewentualnej roli przyczynowej zaburzeń przetwarzania słuchowego w ich patogenezie [12]. Szczególnie wiele miejsca poświęcono w literaturze zależnościom między zaburzeniami przetwarzania słuchowego a SLI (ang. Specific Language Impairment, specyficzne zaburzenie rozwoju językowego) [12-15]. Dzieci z SLI w ujęciu Leonarda to dzieci, u których obserwuje się znaczne ograniczenie zdolności językowych, choć nie występują u nich czynniki takie jak zaburzenia słuchu (obwodowego), niskie wyniki w niewerbalnych testach inteligencji czy uszkodzenia neurologiczne [13]. Nie uczą się one języka łatwo i bez wysiłku. Przyswajanie języka u takich dzieci można usprawnić, ale deficyty językowe nie ustępują szybko. Ponadto, gdy dzieci z SLI osiągają wiek szkolny, są zagrożone trudnościami w nauce czytania [13]. Leonard

${ }^{1}$ Dla ujednolicenia terminologii w niniejszej pracy stosowane są terminy: zaburzenia przetwarzania słuchowego lub APD, które potraktowane zostały jako synonimy z innymi terminami spotykanymi w piśmiennictwie: CAPD, centralne/ośrodkowe zaburzenia przetwarzania słuchowego. 
dostrzega wyraźną zależność pomiędzy SLI a trudnościami na poziomie przetwarzania słuchowego, szczególnie bodźców krótkich i prezentowanych przez krótki czas, jednak podkreśla, że potrzeba jeszcze wielu badań, aby w pełni ustalić charakter tego związku [13].

Do lepszego zrozumienia zależności opisywanych powyżej zjawisk z pewnością przyczyniłoby się wypracowanie „złotego standardu” i powszechne jego wdrożenie w powstępowanie diagnostyczne zaburzeń przetwarzania słuchowego oraz ujednolicenie kryteriów kwalifikujących do normy i patologii, które obecnie mogą różnić się pomiędzy poszczególnymi ośrodkami $[5,10,16]$. Pozwoliłoby to na prowadzenie zakrojonych na szeroką skalę badań porównawczych oraz umożliwiło konstruowanie coraz bardziej efektywnych programów rehabilitacji.

\section{Materiał i metody}

Celem pracy jest przedstawienie studium przypadku dziecka z deficytem językowym i trudnościami szkolnymi, u którego stwierdzono współistniejące zaburzenia przetwarzania słuchowego. Intencją autorek niniejszego artykułu jest szczegółowe przeanalizowanie procesu diagnostycznego oraz płynących z niego wniosków w celu wyjaśnienia, w ujęciu wielodyscyplinarnym, trudności obserwowanych u dziecka. Praca dotyczy 8-letniego chłopca - ucznia II klasy szkoły podstawowej, który został objęty specjalistyczną opieką IFPS ze względu na utrzymujące się, mimo prowadzonej terapii logopedycznej, deficyty językowe, zaburzenia artykulacji, liczne trudności słuchowe oraz pogłębiające się problemy szkolne.

$\mathrm{W}$ toku postępowania diagnostycznego przeprowadzono następujące działania, których wyniki poddano szczegółowej analizie:

- wywiad medyczny, logopedyczny, pedagogiczny i psychologiczny zebrany z wykorzystaniem opracowanej w IFPS Karty wywiadu oraz analiza dotychczasowej dokumentacji medycznej,

- diagnostyka audiologiczna: audiometria tonalna, audiometria impedancyjna, TEOAE (otoemsja akustyczna),

- ocena logopedyczna, obejmująca mowę czynną i bierną, artykulację, słuch fonemowy, zarówno na podstawie wyników badań (Całościowe badanie logopedyczne ${ }^{2}$ D. Emiluty-Rozya, Logopedyczny test dla dzieci i młodzieży I. Michalak-Widery, Tablice do badania słuchu fonematycznego I. Styczek), jak i obserwacji w sytuacjach spontanicznych, - ocena psychologiczna: WISC-R (Wechsler Intelligence Scale For Children - Revised - Skala Inteligencji Wechslera dla Dzieci - Wersja Zmodyfikowana), SRD (Skala Ryzyka Dysleksji) M. Bogdanowicz, testy uwagi z baterii Test of Attention Performance - Alertness (Czujność ${ }^{3}$ ), Divided Attention Auditory-Visual (Podzielność uwagi słuchowo-wzrokowej ${ }^{4}$ ),

- ocena centralnych funkcji słuchowych: FPT (Frequency Pattern Test - Test oceny sekwencji tonów różniących się częstotliwością), DPT (Duration Pattern Test - Test oceny sekwencji tonów różniących się długością), DDT (Dichotic Digits Test - Dwudzielny test cyfrowy).

\section{Wywiad}

Chłopiec w momencie przeprowadzania diagnozy miał ukończone 8 lat. Dane z wywiadu okołoporodowego wskazują, że urodził o czasie (37 Hbd) z prawidłowo przebiegającej ciąży bliźniaczej. Poród odbył się przez cesarskie cięcie, chłopiec urodził się jako drugi i otrzymał 10 punktów w skali Apgar. Wynik przesiewowego badania słuchu był prawidłowy.

Dalszy rozwój dziecka z wyjątkiem rozwoju mowy przebiegał harmonijnie. Kamienie milowe rozwoju ruchowego osiągane były o czasie. Dane dotyczące rozwoju mowy badanego pacjenta są niepełne (m.in. brak informacji na temat rozwoju przedjęzykowego: etapów głużenia, gaworzenia, nieprecyzyjne datowanie dotyczące dalszych etapów), jednak z zebranego wywiadu jednoznacznie wynika, że przebiegał on $z$ opóźnieniami. Pierwsze słowa chłopiec wypowiedział najprawdopodobniej o czasie, ale do wieku 4 lat jego rozwój mowy wciąż znajdował się w fazie wypowiedzeń jednowyrazowych. Mowa bardzo długo była niezrozumiała dla osób spoza najbliższego otoczenia ze względu na liczne zaburzenia substancji fonicznej i struktury wyrazów. W wieku 7 lat chłopiec wciąż miał trudności w budowaniu zdań rozwiniętych, poprawnych pod względem gramatycznym oraz w swobodnym tworzeniu wypowiedzi słownych. Według relacji matki ojciec dziecka w dzieciństwie zmagał się z podobnymi trudnościami. Chłopiec w okresie przedszkolnym (w wieku od 3 do 6 lat) mieszkał za granicą i miał kontakt $\mathrm{z}$ językiem angielskim. Językiem dominującym pozostawał język polski. Dziecko nie przyswoiło ani w sposób czynny, ani w sposób bierny języka angielskiego. Jego siostra (bliźniaczka) poddana identycznej stymulacji językowej rozwijała mowę bez opóźnień. Chłopiec ze względu na powolne postępy w rozwoju mowy był badany przez neurologa oraz psychiatrę. Wynik wykonanego badania EEG był prawidłowy, wykluczono też całościowe zaburzenia rozwoju. W momencie przyjęcia dziecka do IFPS w wieku 8 lat jego rodzice zgłaszali utrzymujące się trudności językowe oraz zaburzenia artykulacji, mimo prowadzonej od 5 rż. terapii logopedycznej. Tempo nabywania nowych umiejętności w opinii rodziców jest niezadowalające.

Oprócz problemów językowych rodzice dziecka wskazywali także na szereg trudności słuchowych. Mimo dobrego rozumienia poleceń prostych, chłopiec miewa trudności z rozumieniem dłuższych wypowiedzi, z nadążaniem za szybkimi wypowiedziami oraz rozumieniem mowy w hałasie (w klasie szkolnej). Często prosi o powtarzanie poleceń, wymaga przeformułowania komunikatów słownych. Czasem nieadekwatnie odpowiada na pytania. Prezentuje objawy nadwrażliwości słuchowej. Ma też trudności w uczeniu się z wykorzystaniem słuchu. Mimo wielu ćwiczeń ma kłopoty z zapamiętaniem nazw dni tygodnia, miesięcy, z trudem uczy się wierszyków na pamięć. Dobrze radzi sobie natomiast w zakresie pamięci wzrokowej. Od ok. 5 rż. uwidaczniają się u niego problemy z koncentracją uwagi. Chłopiec, aby się skupić, potrzebuje idealnej ciszy. Ze względu na tendencję do łatwego rozpraszania się, lepiej pracuje indywidualnie niż w grupie. Dziecko niewiele treści wynosi z lekcji.

\footnotetext{
${ }^{2} \mathrm{~W}$ przypadku nazw testów zastosowano pisownię oryginalną, uwzględniając użycie wielkich i małych liter.

${ }^{3}$ Propozycja tłumaczenia K. S.

${ }^{4}$ Propozycja tłumaczenia K. S.
} 
Słuchając nauczyciela, przyswaja podane informacje powoli, szybko zapomina, co zostało powiedziane. Największą trudność sprawia chłopcu język polski oraz nauka języka angielskiego. Dobrze natomiast, zdaniem rodziców, radzi sobie z matematyką. Zaczyna samodzielnie czytać, jednak nauka tej umiejętności przychodzi mu z wysiłkiem. Chłopiec czyta powoli, głoskuje i ma problemy z dokonaniem wtórnej syntezy, przekręca wyrazy, nie zawsze rozumie, co przeczytał. Ma też trudności z wyraźnym pisaniem, trzymaniem pisma $\mathrm{w}$ liniaturze, popełnia różnorodne błędy w pisowni (m.in. zastępuje, opuszcza, dodaje litery, przestawia ich kolejność). Jest leworęczny.

\section{Ocena audiologiczna}

Pierwszym etapem w procesie diagnostycznym było przeprowadzenie badań audiologicznych mających na celu wykluczenie niedosłuchu o charakterze obwodowym jako potencjalnej przyczyny trudności dziecka. W przypadku omawianego chłopca wyniki badań otoemisji akustycznej, audiometrii tonalnej oraz audiometrii impedancyjnej wskazały na prawidłową czułość słuchu.

\section{Ocena mowy czynnej i biernej}

Ocena mowy czynnej i biernej dziecka opierała się nie tylko na wynikach przeprowadzonych prób badawczych pochodzących z Całościowego badania logopedycznego D. Emiluty-Rozya, lecz także na obserwacji zachowań językowych w naturalnych sytuacjach komunikacyjnych w trakcie indywidualnej terapii logopedycznej w IFPS. Nie wszystkie obserwowane trudności mogły bowiem zostać wykryte przy użyciu dostępnych narzędzi badawczych. Na podstawie zebranych wyników można wysunąć wniosek ogólny, iż w mowie dziecka obserwuje się nieprawidłowości o różnym stopniu nasilenia we wszystkich podsystemach języka. Chłopiec ma trudności w stosowaniu i rozumieniu reguł syntaktycznych, morfologicznych, semantycznych oraz fonetyczno-fonologicznych. Wykazuje się dobrym rozumieniem poleceń prostych, jednak nie zawsze prawidłowo rozumie dłuższe i bardziej złożone wypowiedzenia. Budowane przez niego teksty cechuje dominacja zdań pojedynczych. Składnia jest uboga, często występują wypowiedzi niekompletne, co wynika z niepełnych schematów składniowych. Obserwuje się też niewielkie zróżnicowanie pojawiających się części mowy (głównie rzeczowniki i czasowniki). Pod względem oceny form morfologicznych w zarejestrowanych wypowiedziach zdarzają się błędne wybory końcówek fleksyjnych, częste nieuwzględnianie form obocznych tematu fleksyjnego. Chłopiec ma też trudności z dokonywaniem operacji słowotwórczych. Zasób słownictwa czynnego pacjenta jest ubogi, charakterystyczny dla dziecka młodszego. Szczególne trudności można zaobserwować na poziomie używania i rozumienia bliskoznaczności, analogii słownych oraz określeń dotyczących układu w czasie i przestrzeni. Uwidaczniają się także problemy $\mathrm{z}$ aktualizacją wyrazu na żądanie pomimo jego rozumienia oraz z szybkością skojarzeń werbalnych. Słuchowa pamięć słowna jest obniżona.

\section{Ocena artykulacji}

Do oceny artykulacji użyto Logopedycznego testu dla dzieci i młodzieży I. Michalak-Widery. Badanie pod kątem różnych patomechanizmów zaburzeń dźwięków mowy wykluczyło wpływ przyczyn o charakterze anatomiczno-funkcjonalnym (budowa i sprawność aparatu artykulacyjnego oraz przebieg funkcji fizjologicznych w obrębie narządu żucia) na obserwowane trudności artykulacyjne. W wyniku badania stwierdzono występowanie substytucji w obrębie trzech szeregów głosek dentalizowanych oraz cechy mowy bezdźwięcznej. Szereg głosek przedniojęzykowo-dziąsłowych [š ž č ž] jest wymawiany w postaci głosek przedniojęzykowo-zębowych [s z c 3] lub prepalatalno-zazębowych [s' z' c' 3']. Szereg głosek przedniojęzykowo-zębowych [ $\mathrm{s} \mathrm{z} \mathrm{c}_{3}$ ] jest realizowany prawidłowo lub jako głoski prepalatalno-zazębowe [s' z' c' 3']. Głoski prepalatalne [ś, ź, ć, ́́] substytuowane są poprzez głoski prepalatalno-zazębowe [s' z' c' 3']. W obrębie głosek dentalizowanych obserwuje się też częste, mniej stałe substytucje dotyczące cechy stopnia zbliżenia narządów mowy: głoski szczelinowe bywają przez pacjenta zamieniane na głoski zwarto-szczelinowe. Odnotowuje się też zaburzenia w realizacji cechy dźwięczność - bezdźwięczność, manifestujące się częściowym ubezdźwięcznianiem spółgłosek dźwięcznych właściwych, co w efekcie daje realizację dźwięków pośrednich. Problem ten dotyczy w największym stopniu spółgłosek zwarto-wybuchowych, a także spółgłosek zwarto-szczelinowych. W strukturze dłuższych i mniej znanych wyrazów pojawiają się metatezy głoskowe i sylabowe. Obserwowane u pacjenta zaburzenia dźwięków mowy i struktury wyrazów manifestują się więc jako:

- mylenie dźwięków mowy o podobnych częstotliwościach,

- mylenie dźwięków mowy o podobnej długości,

- mylenie kolejności dźwięków mowy.

\section{Ocena słuchu fonemowego i umiejętności fonologicznych}

Do oceny słuchu fonemowego (odróżnianie/utożsamianie dwóch wypowiedzi różnych/takich samych fonologicznie [17]) posłużono się tablicami Ireny Styczek. Na podstawie ilustracji obrazujących pary minimalne sprawdzono różnicowanie opozycji fonologicznych samogłoskowych oraz spółgłoskowych pod względem dźwięczności, miejsca artykulacji, stopnia zbliżenia narządów mowy i udziału podniebienia miękkiego. Chłopiec wykazał się umiejętnością różnicowania podanych na drodze słuchowej paronimów, gdy były one wymawiane powoli i z przesadną artykulacją. Gdy tempo mowy było swobodniejsze, a artykulacja bardziej naturalna, pojawiały się błędne wskazania w opozycjach spółgłoskowych dotyczących cechy dźwięczności, miejsca artykulacji oraz stopnia zbliżenia narządów mowy. Błędne wskazania dotyczyły najczęściej tych opozycji fonologicznych, które mylone są $\mathrm{w}$ mowie. Można wnioskować, że w swobodnych sytuacjach komunikacyjnych chłopiec wykazuje się zmniejszoną zdolnością dyskryminacji dźwięków mowy. Dziecko prezentuje też trudności na poziomie umiejętności fonologicznych rozumianych jako świadomość struktury oraz różnic w budowie wyrazów (dzielenie wyrazu na głoski i złożenie wyrazu z podanych głosek) oraz metafonologicznych - opartych na świadomych operacjach wykonywanych na materiale językowym (wskazywanie głosek, którymi różnią się dwa wyrazy, nazwanie zmiany w strukturze wyrazu) [18]. Według Krasowicz-Kupis umiejętności te mają znaczenie prognostyczne dla nauki czytania [19]. 
Tabela 1. Wyniki WISC-R

Table 1. Results of the WISC-R

\begin{tabular}{lc}
\hline & $\begin{array}{c}\text { Iloraz inteligencji } \\
\text { (uwzględniając efekt Flynna) }\end{array}$ \\
\hline Skala słowna & $(74 ; 92)$ \\
\hline Skala bezsłowna & $(110 ; 130)$ \\
\hline Skala petna & $(94 ; 99)$ \\
\hline
\end{tabular}

\section{Ocena możliwości intelektualnych}

W celu oceny możliwości intelektualnych chłopca i wykluczenia upośledzenia umysłowego jako przyczyny problemów wykonano test WISC-R. Otrzymane wyniki, po uwzględnieniu - zgodnie z zaleceniami Polskiego Towarzystwa Psychologicznego [20] - efektu Flynna, przedstawiono w tabeli 1.

Z 85\% prawdopodobieństwem wynik rzeczywisty chłopca na skali słownej mieści się w granicy wyników przeciętnych, poniżej przeciętnej lub na granicy upośledzenia umysłowego. Najlepsze wyniki w tej skali chłopiec uzyskał w teście Rozumienie, najsłabsze w testach Wiadomości i Arytmetyka. Wyniki rzeczywiste pacjenta otrzymane w skali bezsłownej z 85\% prawdopodobieństwem mieszczą się w granicach wyników ponadprzeciętnych, wysokich lub bardzo wysokich. Najlepsze wyniki w tej skali chłopiec uzyskał w teście Układanki, najsłabsze w teście Uzupełnianie obrazków. Rozpiętość między najniższym a najwyższym wynikiem testu (zarówno w skali słownej, jak i bezsłownej) powyżej drugiego odchylenia standardowego wskazuje na znaczną nieharmonijność rozwoju intelektualnego chłopca. Różnica między skala słowną (odpowiadającą za zdolności poznawcze powiązane z używaniem języka) a bezsłowną (odpowiadającą za rozumowanie na materiale niejęzykowym) jest istotna statystycznie na poziomie ufności 0,05 . Różnica ta powoduje, że z dużą ostrożnością należy interpretować wynik testu w skali pełnej [21]. Biorąc pod uwagę rozkład wyników osiągniętych przez pacjenta, można postawić za Sattlerem [22] hipotezę, że umiejętności oparte na przetwarzaniu wzrokowo-motorycznym sa u badanego chłopca na wyższym poziomie niż umiejętności wymagające przetwarzania słuchowo-językowego.

\section{Testy uwagi}

W ramach oceny psychologicznej przeprowadzono również testy uwagi z baterii Test of Attention Performance: Divided Attention Auditory-Visual oraz Alertness.

Czujność uwagi to zdolność do długotrwałego oczekiwania na pojawienie się ściśle określonego bodźca zwanego sygnałem, a ignorowania pozostałych bodźców zwanych szumem [23]. W czasie testu Alertness pacjent popełnił tylko po jednym błędzie fałszywego alarmu (reakcja na bodziec, który jest szumem/tłem) i chybienia (pominięcie właściwego bodźca), jednak wyniki tego testu wskazują na znacznie wydłużony i zmienny czas reakcji, którego efektem może być „uwaga sinusoidalna”. Przekładać się to może na pomijanie przez chłopca części informacji, w efekcie czego obserwować można np. nierównomierną
Tabela 2. Wyniki testów wyższych funkcji słuchowych Table 2. Results of the tests of central auditory functions

\begin{tabular}{llc}
\hline $\begin{array}{l}\text { FPT (Frequency } \\
\text { Pattern Test) }\end{array}$ & obuusznie & $35 \%$ \\
\hline $\begin{array}{l}\text { DPT (Duration } \\
\text { Pattern Test) }\end{array}$ & obuusznie & $27,50 \%$ \\
\hline & $\begin{array}{l}\text { obuusznie (bez } \\
\text { kierunkowania uwagi) }\end{array}$ & $58 \%$ \\
\cline { 2 - 3 } $\begin{array}{l}\text { DDT } \\
\text { (Dichotic Digits Test) }\end{array}$ & $\begin{array}{l}\text { UP (z ukierunkowaniem } \\
\text { uwagi) }\end{array}$ & $57,50 \%$ \\
\cline { 2 - 3 } & $\begin{array}{l}\text { UL (z ukierunkowaniem } \\
\text { uwagi) }\end{array}$ \\
\hline
\end{tabular}

pracę podczas lekcji. Podzielność uwagi dotyczy możliwości selekcjonowania informacji podawanej jednocześnie dwoma kanałami w tej samej chwili - w tym przypadku kanałem wzrokowym i słuchowym. Wyniki testu Divided Attention Auditory-Visual wskazują na obniżoną podzielność uwagi chłopca: długi czas reakcji na bodziec słuchowy, trudność z utrzymaniem uwagi słuchowej oraz ignorowanie bodźców słuchowych w obecności konkurencyjnych bodźców wzrokowych. Uzyskane rezultaty wskazują też na dużą męczliwość słuchową.

\section{Ocena ryzyka dysleksji}

Zaburzenia percepcji słuchowej oraz zaburzenia rozwoju mowy mogą współwystępować z dysleksją rozwojową. Bogdanowicz wśród objawów dysleksji dzieci w wieku szkolnym wymienia m.in. zaburzenia rozwoju językowego i mowy, tj. wady wymowy, przekręcanie złożonych wyrazów, wypowiedzi niepoprawne pod względem gramatycznym [24]. Z powyższych powodów oraz biorąc pod uwagę objawy zgłaszane przez rodziców, przeprowadzono ocenę ryzyka rozwoju dysleksji przy użyciu Skali Ryzyka Dysleksji. Test został wypełniony przez matkę dziecka, a jego wynik - 67 punktów świadczy o dużym ryzyku zagrożenia dysleksją. Objawy wskazujące na istnienie ryzyka dysleksji występują w największym stopniu w sferach rozwoju obejmujących: funkcje słuchowe, mowę, lateralizację, orientację w czasie, schemacie ciała i przestrzeni oraz uwagę.

\section{Testy wyższych funkcji słuchowych}

W ramach oceny centralnych funkcji słuchowych wykonano testy FPT, DPT, DDT. Otrzymane wyniki przedstawia tabela 2 .

Test FPT służy do oceny rozróżniania wysokości tonów i porządkowania czasowego. Badanie wykonuje się, wykorzystując bodźce o częstotliwości $880 \mathrm{~Hz}$ (dźwięk niski) i $1122 \mathrm{~Hz}$ (dźwięk wysoki). Pacjentowi podaje się sekwencję złożoną z trzech dźwięków, z czego dwa o innej częstotliwości niż trzeci. Badany ma określić kolejność usłyszanych bodźców. Ze względu na długość badania (40 sekwencji) i trudności z utrzymaniem uwagi zdecydowano się na wykonanie wersji badania $\mathrm{z}$ obuuszną prezentacją bodźców. Chłopiec osiągnął wynik poniżej normy, która w literaturze anglojęzycznej dla dzieci ośmioletnich wynosi $42 \%$ [25]. 
Test DPT służy do oceny rozróżniania długości tonów i porządkowania czasowego dźwięków. Badanie wykonuje się, wykorzystując bodźce o długości 250 ms (dźwięk krótki) i 500 ms (dźwięk długi), jego przebieg jest analogiczny jak w teście FPT. Podobnie jak w badaniu opisanym wcześniej DPT wykonano, prezentując bodźce obuusznie, bez ukierunkowania uwagi dziecka. W tym teście badany chłopiec także osiągnął wynik poniżej normy dla jego wieku, która w literaturze anglojęzycznej dla dzieci ośmioletnich wynosi 35\% [25].

Testy dwudzielne (dychotyczne) oceniają integrację obuuszną i separację międzyuszną. W badaniu DDT używa się nazw liczb od 1 do 10. Informację dźwiękową podaje się jednocześnie do obojga uszu, po dwie liczby do każdego ucha. W teście DDT wykonywanym bez kierunkowania uwagi zadaniem pacjenta jest powtórzenie cyfr usłyszanych w obojgu uszach. Test sprawdza integrację obuuszną, preferencję ucha przy wysłuchiwaniu informacji z otoczenia oraz ilościowe wykorzystanie informacji podawanych drogą słuchową. W teście DDT z ukierunkowaniem uwagi sposób prezentacji bodźców jest identyczny jak poprzednio, jednak zadaniem dziecka jest ignorowanie liczb podawanych do jednego ucha i powtarzanie liczb podawanych do ucha drugiego. Test sprawdza separację międzyuszną. W teście DDT bez ukierunkowywania uwagi pacjent powtórzył łącznie 58\% wszystkich informacji, z czego z UP (ucha prawego) 65\%, a z UL (ucha lewego) 52,5\%. Wynik ten jest poniżej normy, która w literaturze anglojęzycznej [25] wynosi $75 \%$ dla UP i $65 \%$ dla UL. Średnia 58\% wskazuje, że pacjent wykorzystuje mniejszą ilość informacji podanej na drodze słuchowej niż przeciętny ośmiolatek. Wynik wskazuje też, iż przy pozyskiwaniu informacji badany chłopiec korzysta z obojga uszu (różnica pomiędzy uszami wynosi $12,5 \%$ ), ale preferuje ucho prawe. Obniżony wynik DDT z ukierunkowaniem świadczy o słabej separacji międzyusznej, obniżonej umiejętności ukierunkowania uwagi i ignorowania bodźców nieistotnych.

\section{Omówienie wyników}

Dane zebrane w wyniku przeprowadzonej oceny logopedycznej oraz istotna różnica $w$ wynikach skali słownej i bezsłownej w testach psychologicznych skłaniają do rozważenia u badanego chłopca diagnozy w kierunku SLI. Diagnoza SLI polega w równym stopniu na stosowaniu kryteriów włączających i wyłączających [13]. W przypadku badanego chłopca spełnia on następujące kryteria wyłączające [13]: prawidłowy wynik obwodowych badań słuchu, prawidłowy iloraz inteligencji w skali niewerbalnej, brak jednoznacznych uszkodzeń neurologicznych, prawidłowa budowa i sprawność aparatu artykulacyjnego. Na podstawie zebranych danych i obserwacji można sądzić, że u chłopca spełnione jest także kryterium braku zaburzeń w dwustronnych interakcjach społecznych, choć nie było to przedmiotem diagnozy psychologicznej. Postawienie pewnej diagnozy SLI nie jest jednak w pełni możliwe, gdyż na gruncie polskim nie zostały opracowane wystandaryzowane testy sprawności językowej, które w sposób jednoznaczny potwierdziłyby, czy badany chłopiec spełnia kryterium włączające SLI, jakim jest znaczny deficyt sprawności językowej stwierdzony na podstawie wyników poniżej określonych dla danego języka norm [13].
Wyniki testów wyższych funkcji słuchowych, zgodnie z wytycznymi ASHA z 2005 r. [9], pozwalają na postawienie u badanego chłopca rozpoznania zaburzeń przetwarzania słuchowego.

Ocena psychologiczna wykazuje istnienie potencjału poznawczego u chłopca, który nie jest w pełni wykorzystany ze względu na obniżony poziom umiejętności wymagających przetwarzania słuchowo-językowego.

Dodatkowo oprócz zaburzeń przetwarzania słuchowego oraz deficytu językowego wiele wskazuje, że chłopiec znajduje się w grupie wysokiego ryzyka dysleksji. Rozwój jego umiejętności szkolnych, przede wszystkim czytania, wymaga dalszej obserwacji i wsparcia terapeutycznego.

Obraz trudności badanego chłopca wpisuje się więc w charakterystykę grupy dzieci często spotykanych w praktyce klinicznej, u których stwierdza się współwystępowanie SLI i/lub dysleksji z APD [12,14,15,26]. Bez względu na to, jak wiele kontrowersji wiąże się z diagnozą ww. zaburzeń, ważniejsze niż samo rozpoznanie może być określenie i zrozumienie deficytów dziecka, a co za tym idzie - dobranie adekwatnej terapii [16]. W przypadku omawianego chłopca badania pokazały, że na drodze słuchowej wykorzystuje on mniej informacji $\mathrm{z}$ otoczenia niż jego rówieśnicy. Prawdopodobne jest, że docierające do niego sygnały - w tym językowe - są niekompletne, co może utrudniać mu budowanie kompetencji językowej. Liczba problemów doświadczanych przez dziecko może wynikać z nasilenia niezdolności do uczenia się ze słuchu [27]. W przypadku zaburzeń artykulacji zasadne wydaje się uwzględnienie APD jako potencjalnego patomechanizmu wpływającego na tempo i efektywność prowadzonych działań logopedycznych, co wykazywały już w swoich badaniach Włodarczyk i Szkiełkowska $[28,29]$. Wyniki testów centralnych funkcji słuchowych u chłopca wskazują na obniżoną zdolność różnicowania częstotliwości dźwięków (a co za tym idzie dźwięków mowy) oraz opracowywania informacji czasowej, co może tłumaczyć kłopoty z odróżnianiem głosek o podobnych częstotliwościach i różnicowaniem czasu ich trwania, a w konsekwencji ich błędną realizację. Trudności ze składaniem sygnałów w całość, np. głosek w wyraz, mogą być wynikiem zaburzonej funkcji integracji czasowej [4]. Sposób kształtowania się wyników testów z baterii Test of Attention Performance sugeruje nie tylko występowanie u badanego chłopca zaburzeń uwagi słuchowej, lecz także to, że pozyskuje on informacje $z$ otoczenia za pomocą kanału wzrokowego, kompensując w ten sposób deficyty słuchowe. W świetle takiej interpretacji wyników pacjenta jak najbardziej uzasadnione jest włączenie do prowadzonej rehabilitacji logopedycznej działań ukierunkowanych na deficyt słuchowy. W sformułowanych zaleceniach znalazło się m.in. zmodyfikowanie sposobu nauczania oraz warunków w szkole i w domu w taki sposób, aby ułatwić dziecku jak najpełniejsze wykorzystanie informacji podawanych na drodze słuchowej oraz włączenie treningu oddziałującego w sposób bezpośredni na określoną funkcję słuchową $[2,3,30]$. Chłopcu zaproponowano uczestnictwo w dwóch prowadzonych w IFPS formach rehabilitacji pacjentów z APD: grupowym, umożliwiającym interakcję i informację zwrotną Aktywnym Treningu Słuchowym [31] oraz w terapii SPS-S Artykulacja (Stymulacja Percepcji Słuchowej - Metoda Skarżyńskiego) będącej 
formą treningu słuchowego opracowanego w IFPS, w którym polimodalnie stymuluje się rozwój słuchowy oraz mowę (przede wszystkim artykulację). W wyniku prowadzonych działań oczekiwany jest: transfer nabytych umiejętności na sytuacje życia codziennego, zredukowanie objawów centralnych zaburzeń przetwarzania słuchowego oraz wzrost szans na sukces edukacyjny dziecka. Zasugerowano także zaangażowanie rodziny oraz terapeutów i nauczycieli pracujących $\mathrm{z}$ dzieckiem $\mathrm{w}$ proces uruchamiania strategii kompensacyjnych wykorzystujących inne zasoby poznawcze chłopca, które mogą zostać użyte do przezwyciężania trudności wynikających z zaburzonych procesów słuchowych $[2,3,30]$. Wskazane jest także wsparcie emocjonalne dziecka oraz jego rodziny, gdyż zazwyczaj dzieci z zaburzeniami przetwarzania słuchowego doświadczają licznych trudności w sferze emocjonalno-społecznej i behawioralnej [32], co prawdopodobnie ma miejsce w omawianym przypadku, choć nie było przedmiotem diagnozy psychologicznej.

\section{Wnioski}

Problem przetwarzania słuchowego leży w kręgu zainteresowań wielu specjalistów. Dzieci z APD ze względu na charakter swoich trudności mogą zgłaszać się po pomoc do audiologa, psychologa, logopedy czy pedagoga. Istotne jest jednak, by proces diagnostyczny miał charakter wielodyscyplinarny. Konieczne wydaje się uwzględnienie wszystkich deficytów dziecka, aby móc dobrać właściwy rodzaj oddziaływań rehabilitacyjnych - odpowiednio skonstruowany program rehabilitacji może bowiem warunkować dobry efekt terapeutyczny. Współistnienie zaburzeń mowy i języka i/ lub trudności szkolnych z zaburzeniami przetwarzania słuchowego generuje potrzebę uzupełnienia rehabilitacji o oddziaływania celowane w deficyt słuchowy. Brak interdyscyplinarnego podejścia oraz wnikliwej analizy wyników przeprowadzonego postępowania diagnostycznego może prowadzić do mylnych wniosków, negatywnie rzutujących na sposób dalszego leczenia, przebieg ścieżki edukacyjnej, a w konsekwencji na przyszłość dziecka.

\section{Piśmiennictwo:}

1. American Academy of Audiology Clinical Practice Guidelines. Guidelines for the diagnosis, treatment and management of children and adults with Central Auditory Processing Disorder, 2010.

2. Bellis TJ. Understanding Auditory Disorders in Children, materiały American Speech-Language Hearing Association: $h t t p: / /$ www.asha.org.

3. Kurkowski M. Zaburzenia przetwarzania słuchowego. W: Grabias S, Kurkowski M, (red.), Logopedia. Teoria zaburzeń mowy. Lublin: Wydawnictwo Uniwersytetu Marii Curie-Skłodowskiej; 2012; 117-28

4. Skoczylas A, Cieśla K, Kurkowski ZM, Czajka N, Skarżyński $\mathrm{H}$. Diagnoza i terapia osob z centralnymi zaburzeniami przetwarzania słuchowego w Polsce. Nowa Audiofonologia, 2012; 1(3): 51-5.

5. Dajos-Krawczyńska K, Piłka A, Jędrzejczak W, Skarżyński H. Diagnoza zaburzeń przetwarzania słuchowego - przegląd literatury. Nowa Audiofonologia, 2013; 2(5): 9-14.

6. Fuente A, McPherson B. Ośrodkowe procesy przetwarzania słuchowego: wprowadzenie i opis testów możliwych do zastosowania u pacjentów polskojęzycznych. Otorynolaryngologia, 2007; 6(2): 66-76.

7. Katz J. Clinical audiology. Baltimore-Hong Kong-London-Sydney; 1994.

8. Chermak GD, Musiek F. Central auditory processing disorders: New perspectives. San Diego, CA: Singular Publishing Group; 1997.

9. American Speech-Language Hearing Association. (Central) Auditory Processing Disorders. Technical Report; 2005.

10. British Society of Audiology. Position Statement. Auditory processing disorder (APD), 2011.

11. Keith RW. Zaburzenia procesów przetwarzania słuchowego postępy w rozumieniu istoty choroby. Otorynolaryngologia, 2004; 3(1): 7-14.

12. Miller CA. Auditory processing theories of language disorders: past, present, and future. Lang Speech Hear Serv Sch, 2011; 42: 309-19.

13. Leonard LB. SLI - Specyficzne zaburzenie rozwoju językowego. Gdańsk: Gdańskie Wydawnictwo Psychologiczne; 2005.
14. Sharma M, Purdy SC, Kelly AS. Comorbidity of auditory processing, language, and reading disorders. J Speech Lang Hear Res, 2009; 52: 706-22.

15. Dlouha O, Novak A, Vokral J. Central Auditory Processing Disorder (CAPD) in children with Specific Language Impairment (SLI). Central auditory tests. Int J Pediatr Otorhinolaryngol, 2007; 71: 903-7.

16. Majak J. Trudności diagnostyczne w zaburzeniach przetwarzania słuchowego u dzieci, Otolaryngologia, 2013; 12 (4): 161-8.

17. Kurkowski M. Audiogenne uwarunkowania zaburzeń mowy. Audiofonologia, 1998; X: 103-9.

18. Koźniewska E, Matuszewski A. Skala umiejętności fonologicznych (Skala F) adaptacja i opracowanie psychometryczne „Prób percepcji słuchowej wyrazów” Barbary Zakrzewskiej. Podręcznik. Warszawa: Centrum Metodyczne Pomocy Psychologiczno-Pedagogicznej; 2003.

19. Krasowicz-Kupis G. Rozwój metajęzykowy a osiągnięcia w czytaniu u dzieci 6-9-letnich. Lublin: Wydawnictwo Naukowe UMCS; 1999.

20. Polskie Towarzystwo psychologiczne. Wyniki w Skali Inteligencji Wechslera dla Dzieci (WISC-R). Efekt Flynna, 2013. www.ptp.org.pl.

21. Krasowicz-Kupis G, Wiejak K. Skala inteligencji Wechslera dla dzieci (WISC-R) w praktyce psychologicznej. Warszawa: Wydawnictwo Naukowe PWN; 2006.

22. Sattler JM. Assessment of children ( $3^{\text {rd }}$ ed.). San Diego: Jerome M. Sattler Publisher; 1988.

23. Strelau J (red). Psychologia. Podręcznik akademicki. Gdańsk: GWP; 2000, 82.

24. Bogdanowicz M. Specyficzne trudności w czytaniu i pisaniu dysleksja rozwojowa. W: Jastrzębowska G, Gałkowski T, red. Logopedia. Pytania i odpowiedzi. Opole: Wydawnictwo Uniwersytetu Opolskiego; 1999, 817.

25. Bellis TJ. Assessment and management of Central Auditory Processing Disorders in the educational setting: From science to practice ( $2^{\text {nd }}$ ed.). Thomson Delmar Learning; 2003.

26. Lewandowska M, Ganc M, Włodarczyk E, Senderski A, McPherson DL, Bednarek D i wsp. Central auditory processes predict reading abilities of children with developmental dyslexia. Journal of Hearing Science, 2013; 3(2): 1-11. 
27. Keith RW. Zaburzenia procesów przetwarzania słuchowego. W: Śliwińska-Kowalska M (red.), Audiologia kliniczna. Łódź: Mediton; 2005, 367-75.

28. Włodarczyk E, Szkiełkowska A, Senderski A, Skarżyński H. Ocena funkcji procesów centralnego przetwarzania słuchowego u dzieci z dyslalią. Standardy Medyczne, 2011; 8(4): 100-9.

29. Włodarczyk E, Szkiełkowska A, Skarżyński H, Piłka A. Zaburzenia artykulacji u dzieci ze współistniejącymi zaburzeniami przetwarzania słuchowego - efekty terapii słuchowej. Otolaryngologia Polska, 2011; 5(IX-X), 65: 339-44.
30. Skoczylas A, Lewandowska A, Pluta A, Kurkowski Z, Skarżyński H. Ośrodkowe zaburzenia słuchu - wskazówki diagnostyczne i propozycje terapii. Nowa Audiofonologia, 2012; $1(1): 11-8$.

31. Rostkowska J, Geremek-Samsonowicz A. Aktywny Trening Słuchowy w terapii centralnych zaburzeń przetwarzania słuchowego. XXXVII Konferencja Naukowo-Szkoleniowa. Problemy otolaryngologii dziecięcej w codziennej praktyce, Lublin; 2014.

32. Rostkowska J, Kobosko J, Kłonica LK. Problemy emocjonalno-społeczne i behawioralne $\mathrm{u}$ dzieci z centralnymi zaburzeniami przetwarzania słuchowego (CAPD) w ocenie rodziców. Nowa Audiofonologia, 2013; 2(1): 29-35. 